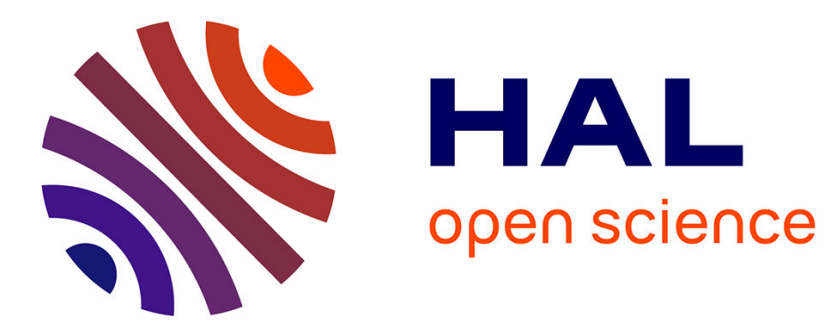

\title{
Comparison of solid-phase bioassays and ecoscores to evaluate the toxicity of contaminated soils.
}

Christine Lors, Jean-François Ponge, Maite Martínez Aldaya, Denis Damidot

\section{To cite this version:}

Christine Lors, Jean-François Ponge, Maite Martínez Aldaya, Denis Damidot. Comparison of solidphase bioassays and ecoscores to evaluate the toxicity of contaminated soils.. Environmental Pollution, 2010, 158 (8), pp.2640-2647. 10.1016/j.envpol.2010.05.005 . hal-00504016

\section{HAL Id: hal-00504016 https://hal.science/hal-00504016}

Submitted on 19 Jul 2010

HAL is a multi-disciplinary open access archive for the deposit and dissemination of scientific research documents, whether they are published or not. The documents may come from teaching and research institutions in France or abroad, or from public or private research centers.
L'archive ouverte pluridisciplinaire HAL, est destinée au dépôt et à la diffusion de documents scientifiques de niveau recherche, publiés ou non, émanant des établissements d'enseignement et de recherche français ou étrangers, des laboratoires publics ou privés. 
1 Comparison of solid-phase bioassays and ecoscores to evaluate the toxicity

2 of contaminated soils

3

4 Christine Lors ${ }^{\mathrm{a}, \mathrm{b}, \mathrm{c}}$, Jean-François Ponge ${ }^{\mathrm{d} *}$, Maite Martínez Aldaya ${ }^{\mathrm{d}}$, Denis Damidot ${ }^{\mathrm{a}, \mathrm{b}}$ 5

aUniversité Lille Nord de France, 1 bis rue Georges Lefèvre, 59044 Lille Cedex, France 7

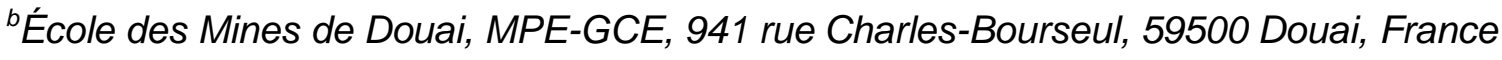

9

10

${ }^{\circ}$ Centre National de Recherche sur les Sites et Sols Pollués, 930 Boulevard Lahure, BP

11537,59505 Douai Cedex, France

12

'Muséum National d'Histoire Naturelle, CNRS UMR 7179, 4 Avenue du Petit-Château,

91800 Brunoy, France

15

16

Abstract

17

Five bioassays (inhibition of lettuce germination and growth, earthworm mortality, inhibition of springtail population growth, avoidance by springtails) were compared, using four coke factory soils contaminated by PAHs and trace elements, before and after biotreatment. For each bioassay, several endpoints were combined in an 'ecoscore', a measure of test sensitivity. Ecoscores pooled over all tested bioassays revealed that most

23 organisms were highly sensitive to the concentration of 3-ring PAHs. When four soils were

24 combined, behavioural tests using the springtail Folsomia candida showed higher

\footnotetext{
* Corresponding author. Tel. +33 6 78930133, fax +33 1 60465719, e-mail: ponge@mnhn.fr
} 
1 ecoscores, i.e. they were most sensitive to soil contamination. However, despite overall

2 higher sensitivity of behavioural tests, which could be used for cheap and rapid

3 assessment of soil toxicity, especially at low levels of contamination, some test endpoints

4 were more sensitive than others, and this may differ from a soil to another, pointing to the

5 need for a battery of bioassays when more itemized results are expected.

6

7 Capsule

8

9 The avoidance test using the soil springtail Folsomia candida is globally more sensitive to $\mathrm{PAH}$ contamination than acute and chronic toxicity bioassays using plants and animals

11 but a battery of tests could reveal better in detail

12

Keywords: PAHs; Trace elements; Contaminated soils; Solid-phase bioassays; Toxicity tests; Avoidance tests; Eisenia fetida; Lactuca sativa; Folsomia candida; Ecoscores

\section{Introduction}

Industrial activities lead to the discharge of a wide range of hazardous chemicals in soils, often far from emission sources (Jones et al., 1989; Nam et al., 2008). Soil pollutants include polycyclic aromatic hydrocarbons (PAHs) and heavy metals, known for

21 potential adverse ecological and toxicological effects (Bispo et al., 1999; Peralta-Videa et al., 2002; Boularbah et al., 2006). Polluted soils also are a threat to ecosystem and human health (Menzie, 1992; Lawlor et al., 1997; Preuss et al., 2003). This threat is generally approached by quantifying the total content of pollutants in the contaminated matrices.

25 Nevertheless this provides only limited information on pollutant bioavailability, and no 26 information on synergetic or antagonistic interactions between pollutants (Juvonen et al.,

27 2000), or on effects on organisms, for which only a biological approach is effective 
1 (Fernández et al., 2005). An ecotoxicological approach, using biological tests on target

2 organisms at different trophic levels, has been recommended for a refined evaluation of

3 environmental hazards in complement of chemical analyses (Bispo et al., 1999; Rila and

4 Eisentraeger, 2003; Fernández et al., 2005; Plaza et al., 2005). Indeed, bioassays

5 integrate the impact of all contaminants including those not considered or detected by

6 chemical analyses, and they take account of additive, synergistic and antagonistic

7 phenomena.

8

\section{8}

Direct toxic effects on survival, growth or reproduction of test organisms may reflect the ecotoxicological potential of contaminated soils (Fent, 2003). Phytotoxicity tests, such as lettuce bioassays, provide a variety of assessment endpoints such as germination and root elongation rates and enzyme activities (Ferrari et al., 1999). Soil invertebrates have also been used in ecotoxicology, in particular earthworms (Fernández et al., 2005; Eom et al., 2007), enchytraeids (Römbke, 2003), springtails (Domene et al., 2007; Eom et al., 2007) and woodlice (Jänsch et al., 2005; Loureiro et al., 2005).

Springtail, earthworm and lettuce soil quality tests have been standardized according to ISO (1999), ISO (1993a, 1998a) and ISO (1993b, 2005a), respectively.

Based on the ability of animals to probe and flee from contaminated places (Best et al., 1978; Salminen and Sulkava, 1996; Gass et al., 2006), avoidance tests have a great potential as early screening tools in lower tier levels of ecological risk assessment, because they are robust, sensitive, cost-effective, ecologically relevant and rapid (Natalda-Luz et al., 2004, 2008a). Avoidance tests are now currently performed with earthworms (Loureiro et al., 2005; Natal-da-Luz et al., 2008a, b; Garcia et al., 2008; De Silva and Van Gestel, 2009; Owojori and Reinecke, 2009), enchytraeids (Amorim et al., 2008; Loureiro et al., 2009; Kobetičová et al., 2009), woodlice (Loureiro et al., 2009) and springtails (Heupel, 2002; Martínez Aldaya et al., 2006; Natal-da-Luz et al., 2008a, b, 2009) and an 
1 international standard for the assessment of soil quality using earthworm avoidance tests 2 exists (ISO, 2008a).

Several studies compared some toxicity and avoidance endpoints (Greenslade and Vaughan, 2003; Loureiro et al., 2005; Martínez Aldaya et al., 2006), but a comparison between tests commonly used for the biological assessment of soil quality is clearly lacking, and studies using a battery of soil and aquatic test organisms did not include avoidance endpoints (Fernández et al., 2005; Pandard et al., 2006; Domene et al., 2008).

Such a comparison should be valid both for scaling toxicity and behavioural tests according to their sensitivity as early screening tools, and for pooling them in a bulk index of soil toxicity.

The reported work evaluates the toxicity of contaminated soils by comparing a variety of solid-phase bioassays applied to $\mathrm{PAH}$-contaminated soils issued from former coke sites in northern France. Studied soils differed by their PAH content and the presence or not of a mixed pollution by heavy metals and/or cyanides. The aims of our study were: (1) to characterize contaminated soils using ecotoxicological (including behavioural endpoints) and chemical analyses, (2) to estimate the likely relationships between pollutants and toxicity responses, (3) to compare the sensitivity of toxicity tests representing different trophic and toxicity levels with the Folsomia candida (Collembola) avoidance test. Toxicity tests relied on the germination and growth of the lettuce Lactuca sativa (Asteraceae) and on the survival and reproduction of the springtail $F$. candida (Isotomidae) and the earthworm Eisenia fetida (Lumbricidae). Two alternative hypotheses were (1) either a test or a group of tests gives a better response to all soils and thus could be used preferentially as a sensitive indicator of soil quality, its performance being measured by an 'ecoscore', or (2) each test or group of tests exhibits a specific response 
1 and as a consequence is not enough to assess soil quality, in which case several

2 bioassays are necessary.

2. Materials and methods

\subsection{Soil samples}

7

Experiments were carried out on PAH-contaminated soils from three industrial sites located in the North of France, the main activity of which was the distillation of coal tar. Soil 1 was fairly polluted with a mixture of PAHs, cyanides and heavy metals. Soil 2 was recovered after 18 months of windrow biotreatment. Despite bioremediation, this soil was still characterized by a high content of PAHs, cyanides and heavy metals. Contrary to Soil 2, Soil 3 was only polluted by PAHs, with a concentration similar to that of Soil 2. In the same site a windrow biotreatment was applied to this soil and Soil 3T was sampled after six months of biotreatment (Lors et al., 2009). After biotreatment, Soil 3T showed a PAHs concentration lower than that of Soil 1.

Unpolluted soils were also sampled in the three studied sites in uncontaminated areas (Table 2), which were used as controls in the avoidance test and as a matrix of dilution in toxicity bioassays. Previous chemical and ecotoxicological analyses were performed on control soils, which did not reveal any toxicity.

\subsection{Chemical analyses}

Soil $\mathrm{pH}_{\text {water }}$ was measured using a Consort ${ }^{\circledR} \mathrm{C} 83 \mathrm{pH}$-meter fitted with a glass electrode corrected for temperature and a Schott ${ }^{\circledR}$ box with Ingold ${ }^{\circledR}$ combined electrodes, according to ISO (2005b). Total organic carbon concentration was obtained from total 
1 carbon and inorganic carbon contents, determined with a TOC-5000A Shimatzu ${ }^{\circledR}$

2 analyser, according to ISO (1995a). Total organic nitrogen concentration was determined

3 by the Kjeldahl method, according to ISO (1995b). Total phosphorus as well as metals

4 (As, Cd, Co, Cr, Cu, Ni, Pb, Zn) were dosed by Inductive Coupled Plasma Atomic

5 Emission Spectrometry (ICP-AES) in a 138 Ultrace Jobin Yvon ${ }^{\circledR}$ analyser after hot

6 hydrofluoric and perchloric acid digestion of solid phase, according to ISO (2001, 2008b).

7

Concentrations of the 16 PAHs of the US-EPA list (Verschueren, 2001) were measured using High Performance Liquid Chromatography (HPLC) in a 2690 HPLC Waters ${ }^{\circledR}$ analyser fitted with an ultraviolet inverted phase C 18 Supelco ${ }^{\circledR}$ column (length

$11250 \mathrm{~mm}$, internal diameter $2.1 \mathrm{~m}$ ) coupled to a 996 Waters $^{\circledR}$ UV photodiode array detector 12 according to ISO (1998b), after extraction by dichloromethane/acetone (50/50 v/v) using 13 the Accelerated Solvent Extractor Dionex ${ }^{\circledR}$ ASE 200. Total cyanides were determined 14 according to ISO (2003). All chemical analyses were done in triplicate.

\subsection{Toxicological analyses}

Toxicity results were the responses of test organisms according to concentration of soil samples in test media $(\%, w / w)$. NOEC was the highest effective concentration at which no significant effect was detected, while $\mathrm{EC}_{10}, \mathrm{EC}_{20}$ and $\mathrm{EC}_{50}$ were the calculated concentrations at which the measured endpoint was reduced to $10 \%, 20 \%$ and $50 \%$ of the control value, respectively. Toxic effects were also calculated as percent inhibition at the highest concentration of the contaminated soil and as Toxic Units or TU (= $\left.100 / \mathrm{EC}_{50}\right)$. In mortality tests (endpoint survival), results were expressed as lethal concentrations reducing survival by $10 \%, 20 \%$ and $50 \%\left(\mathrm{LC}_{10}, \mathrm{LC}_{20}\right.$ and $\mathrm{LC}_{50}$, respectively) compared to controls. 
Phytotoxicity tests were conducted according to ISO (1993b, 2005a), using only $L$. . . sativa (lettuce). Tests were carried out in a chamber at $20 \pm 2^{\circ} \mathrm{C}$ under constant illumination (4000-7000 Ix), with a 16:8 day-night light cycle. Assays were conducted in plastic pots (diameter $11 \mathrm{~cm}$, height $10 \mathrm{~cm}$ ) containing $200 \mathrm{~g}$ of contaminated substrate moistened at $70-80 \%$ water-holding capacity. The moisture level was maintained constant by adding distilled water every day. Twenty seeds were placed at the surface of the test medium. Five concentrations of the contaminated soil were tested: $100 \%, 60 \%, 35 \%, 20 \%$ and $10 \%, w / w$. For each concentration, analyses were done in triplicate. Seedling emergence (\%) was determined after seven days of exposure. Seedling wet and dry biomasses were measured after 14 days of exposure. Results were expressed as percent lettuce germination and growth in comparison with controls.

4
(1993a). The survival of adult earthworms was determined after 14 days of exposure. Ten individuals were placed in a glass jar containing $500 \mathrm{~g}$ of wet soil at $70-80 \%(\mathrm{w} / \mathrm{w})$ moisture. Various concentrations of the studied soil in the control soil were tested in the range $1-100 \%$. For each tested concentration, four replicate cultures were done. The jars were exposed in an environmental chamber at $20 \pm 1^{\circ} \mathrm{C}$ under a 16:8 (400 - $\left.800 \mathrm{Ix}\right)$ daynight light cycle. Results were expressed as percent mortality in comparison with controls.

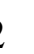
according to Martínez Aldaya et al. (2006). Population growth responses were assessed by introducing 10 parthenogenetic females of $F$. candida into each of five rearing chambers (crystal polystyrene boxes $45 \mathrm{~mm}$ diameter, $25 \mathrm{~mm}$ height), fifth-filled with the control soil or with the polluted soil at $0.35 \%, 1 \%, 5 \%, 10 \%, 50 \%$ and $100 \%$ concentration. A small amount of dry cattle dung powder was added above the soil substrate before animals were introduced, then boxes were incubated at $20^{\circ} \mathrm{C}$ in darkness during 40 days. 
1 At the end of the experiment, the whole population was collected, using forceps and

2 flotation.

Avoidance tests were conducted according to Martínez Aldaya et al. (2006) and Lors et al. (2006). They were performed in sterile crystal polystyrene Petri dishes $(55 \mathrm{~mm}$ diameter, $10 \mathrm{~mm}$ height), the bottom of which was lined with two half-disks of glass-fibre filter paper (50mm diameter). The entire surface of each half-disk was covered with a paste of soil which was prepared just beforehand by adding enough deionized water to make the soil plastic. One half-disk was covered with the control soil, the other with the polluted soil diluted at the same concentrations as for population growth experiments. The two half-disks were separated by a $2 \mathrm{~mm}$ space line, at the centre of which a single individual of $F$. candida was deposited. Animals selected for avoidance tests were naive adults or subadults and came from the same batch culture originating from a single female collected in the Park of the Brunoy Laboratory. Batch cultures had been maintained on fine quartz sand with ground cow dung as food for more than two years. The position of the animal was recorded each 20 min up to $100 \mathrm{~min}$. Twenty replicates, in two successive batches of ten, were followed together under a Sharp ${ }^{\circledR}$ fluorescent illuminator in a chamber at $20^{\circ} \mathrm{C}$. The position of the animal was checked through the cover lid by help of a hand-held magnifying glass. Blank experiments did not detect any light gradient which could bias the results (Salmon and Ponge, 1998). Totals of five counts over 100 min for each Petri dish were used as scores for testing differences between control and polluted sides.

Toxic effects were calculated as percentages of inhibition at a given concentration or as $L_{C X}$ values. Percent inhibition was determined with respect to the control soil. $L_{C x}$ values were calculated following adjustment of data to a log-probit logistic model (Litchfield and Wilcoxon, 1949). NOEC was the highest concentration tested that did not 
1 significantly differ from control at $5 \%$ risk level. LOEC was not used and was replaced by

$2 \quad \mathrm{EC}_{10}$ or $\mathrm{LC}_{10}$. Toxicity values were also expressed into Toxic Units (TU), using the formula $3 \mathrm{TU}=100 / \mathrm{EC}(\text { or LC) })_{50}$

4

From five ecotoxicological parameters $\mathrm{E}(\mathrm{L}) \mathrm{C}_{50}, \mathrm{E}(\mathrm{L}) \mathrm{C}_{20}, \mathrm{E}(\mathrm{L}) \mathrm{C}_{10}$, NOEC, and \%

6 inhibition, 'ecoscores' were calculated by giving to each value a score between 0 and 3 as

7 a function of its intensity, according to the following scales ( $x=$ endpoint value):

\section{Results}

- for $\mathrm{E}(\mathrm{L}) \mathrm{C}_{50}, \mathrm{E}(\mathrm{L}) \mathrm{C}_{20}, \mathrm{E}(\mathrm{L}) \mathrm{C}_{10}$, and NOEC

○ $0=$ no effect $(x>100)$

$\circ \quad 1=$ weak effect $(50<x \leq 100)$

○ 2 = medium effect $(20<x \leq 50)$

- 3 = strong effect $(x \leq 20)$

- $\quad$ for $\%$ inhibition

$0=$ no effect $(x \leq 5)$

○ 1 = weak effect $(5<x \leq 20)$

$\circ \quad 2$ = medium effect $(20<x \leq 60)$

○ $\quad 3$ strong effect $(x>60)$

Then the five unit scores were summed up and the total was rescaled to 100 for maximum intensity of the five endpoints.

used to explore possible linear relationships between physicochemical parameters and toxicity endpoints. All calculations were done with the statistical software XSTAT ${ }^{\circledR}$ (Addinsoft, Paris, France) using Excel ${ }^{\circledR}$ (Microsoft, Redmond, WA).

Correlation analysis, using Pearson product-moment correlation coefficient, was 


\subsection{Chemical data}

(n)

Physicochemical characteristics of studied soils are reported in Table 1. Moisture content was close to $20 \%(\mathrm{w} / \mathrm{w})$ in Soils 2,3 and 3 T whereas it was only $10 \%$ in Soil 1 . All soils had a pH value close to 8 and most of their carbon was organic. However, Soil 2 presented a much higher amount of organic carbon (44\%) compared to Soils 1 and 3 (< $10 \%)$. This difference could be explained by the addition of compost during windrow treatment of Soil 2, as confirmed by high $\mathrm{N}$ and $\mathrm{P}$ amounts. Concentrations of PAHs and trace elements (cyanides and heavy metals) in tested and control soils are presented in Table 2 and the 16 PAHs of the US-EPA list are detailed in Table 3 for the four tested soils. Concentrations of trace elements were compared to the geochemical background in the North of France (Sterckeman et al., 2002).

Soil 3 was mainly contaminated by organics, since heavy metals and cyanides were present in low concentrations (Table 2). Concentrations of heavy metals were close to the geochemical background, to the exception of slightly more Zn. Cyanides did not exceed $1 \mathrm{mg} \cdot \mathrm{kg}^{-1}$. Soil 3 was heavily polluted with PAHs, with a global content of $3 \mathrm{~g} \cdot \mathrm{kg}^{-1}$ dry soil (Table 2). Most PAHs were 2-, 3- and 4-ring compounds (Table 3), 3-ring PAHs being dominant (44\% of $\Sigma 16 \mathrm{PAHs}$ ), followed by 2 - and 4-ring compounds, which amounted to 28 and $20 \%$ of $\Sigma 16$ PAHs, respectively (Fig. 1). Among 3-ring PAHs, phenanthrene was dominant (49\%), followed by acenaphtene, fluorene and anthracene in similar concentrations (17, 16 and $18 \%$, respectively). Fluoranthene was the main 4-ring PAH (51\%), followed by pyrene (29\%). The 5- and 6-ring PAHs were hardly represented in Soil 3, amounting to 5 and $2 \%$ of $\Sigma 16$ PAHs, respectively (Fig. 1).

Soil 3T, i.e. Soil 3 after six months of windrow biotreatment, showed a much lower PAH concentration, roughly one tenth that of untreated soil (Table 1). Biotreatment led to 
1 a strong degradation of 2-, 3- and 4-ring PAHs, which decreased by 98,97 and $82 \%$,

2 respectively (Fig. 1). Among the remaining compounds, 4-ring PAHs were most represented (42\% of $\Sigma 16 \mathrm{PAHs}$ ), amounting to $146 \mathrm{mg} \cdot \mathrm{kg}^{-1}$ dry soil. As expected, the concentration of total trace elements did not decrease nor increase after biotreatment.

Contrary to Soil 3, Soil 2 showed a dual organic and inorganic contamination. Its total content of $\mathrm{Zn}, \mathrm{Pb}, \mathrm{Cu}$ and $\mathrm{Cd}$ was close to $1 \mathrm{~g}^{\mathrm{kg}}{ }^{-1}$ dry soil, i.e. 8 times the geochemical background (Table 2). Cyanides were in considerable amount in Soil 2, about 70 mg. $\mathrm{kg}^{-1}$ dry soil. This soil was also highly polluted in PAHs (Table 2), to the same level as Soil 3 ( $\Sigma 16$ PAHs $=3.69 \mathrm{~g} \cdot \mathrm{kg}^{-1}$ dry soil). Despite similar global amounts of PAHs in Soils 2 and 3, their distribution was different (Fig. 1). Soil 2 was dominated by 4-ring compounds, which amounted to $50 \%$ of $\Sigma 16$ PAHs (1727 mg.kg-1 dry soil), with fluoranthene as the main 4-ring compound (36\%), followed by pyrene, benzo[a]anthracene and chrysene (Table 3). The 3-ring PAHs represented only $17 \%$ of $\Sigma 16$ PAHs (624 mg kg-1 dry soil), probably due to partial degradation during windrowing. The predominance of phenanthrene (49\%) was also noticeable along with a smaller proportion of anthracene (33\%). The 5- and 6-ring PAHs were also present in higher amounts in Soil 2 than in Soil 3 (Fig. 1). Globally, Soil 2 was thus polluted by PAHs of higher molecular weight than Soil 3.

Soil 1 also presented a mixed pollution (Table 2). However, PAHs, cyanides and heavy metals were in lower amounts than in Soil 2. The concentration of PAHs was about 1 g. $\mathrm{kg}^{-1}$ dry soil, with 3- and 4-ring PAHs most represented, amounting each to $40 \%$ of $\Sigma 16$ PAHs, i.e. around $300 \mathrm{mg} \cdot \mathrm{kg}^{-1}$ dry soil (Fig. 1). Anthracene, phenanthrene and fluoranthene were the main 3- and 4-ring compounds (Table 3). Within heavy metals, only Cu and As showed contents about three times the geochemical background. Cyanide concentration of Soil 1 was ten times less than in Soil 2. 


\subsection{Acute and chronic toxicity endpoints}

Lettuce germination bioassays indicated that Soil 3 was highly toxic to seeds (ecoscore 93\%), and that it lost totally its toxicity after 6-month biotreatment (ecoscore $0 \%$ ). Soils 1 and 2 exhibited about half the toxicity of Soil 3, as ascertained by their ecoscore ( $47 \%$ each). The germination of lettuce seeds was inhibited by $71 \%$ in Soil 3 , compared to about $20 \%$ in Soils 1 and 2 (Table 4). No inhibition of germination was observed in Soil 3T. It must be noticed that ecoscores equalized differences between Soils 1 and 2 when comparing $\mathrm{EC}_{20}$ and $\mathrm{EC}_{50}$ separately. Similarly, the growth of $L$. sativa was strongly inhibited by Soil $3(80 \%)$, while Soils 1 and 2 inhibited it to a weak extent $(0.7$ and $10 \%$, respectively). Ecoscores embraced the inhibition of growth at the highest concentration tested and weaker toxic effects which could be observed at lower concentration (Table 5). The ecoscore for growth inhibition amounted to $93 \%$ for Soil 3 (same value as for germination inhibition), while it remained low for Soils 1 and 2 (13\% and $20 \%$, respectively). After biotreatment, Soil 3 totally lost its toxic effects towards lettuce growth. Thus, according to the two lettuce endpoints, Soil 3 appeared highly toxic

18 (acute toxicity), while Soils 1 and 2 had a moderate effect on this organism. According to ecoscores, lettuce germination appeared more sensitive than lettuce growth. showed that Soil 3 was highly toxic (inhibition rate 100\%, ecoscore 100\%), but contrary to lettuce germination and growth inhibition, Soil 1 did not affect at all the survival of E. fetida (inhibition 0\%, ecoscore 0\%). Soil 2 was at an intermediate level and Soil 3 after biotreatment (Soil 3T) did not reveal any residual toxicity (Table 6). 
In the springtail population growth test (chronic toxicity), Soil 3 appeared highly

2 toxic, as in lettuce and earthworm acute toxicity tests, with an inhibition rate and an ecoscore of $100 \%$ (Table 7). According to raw data (not shown), acute toxicity of Soil 3 was exemplified by the total disappearance of the population of $F$. candida within the duration of the experiment, even when this soil was diluted at $5 \%$. Soils 1 and 2 were not classified in the same manner as in lettuce and earthworm bioassays. Soil 2 did not elicit any response by $F$. candida despite its pollution (inhibition rate and ecoscore $0 \%$ ), while Soil 1 inhibited partially its population growth (inhibition 64\%, ecoscore 60\%). Contrary to other toxicity bioassays, a weak but significant response of population growth was detected after 6 -month biotreatment in Soil $3 \mathrm{~T}$. The $\mathrm{EC}_{10}$ value indicated that $10 \%$ of the full response was obtained at $5 \%$ concentration of the contaminated soil, and the inhibition rate was $27 \%$ when $F$. candida was grown on the pure soil (highest concentration used in the experiment). This resulted in an ecoscore of $53 \%$, quite different from the ecoscore of $0 \%$ obtained with the other three bioassays.

\subsection{Behavioural endpoint}

According to ecoscores and inhibition rates, Soil 3 (before biotreatment) appeared highly repellent (ecoscore 100\%, inhibition rate 100\%). Soils 1 and 2 were also repellent, although at a lower level (ecoscores $80 \%$ and $67 \%$, respectively), while the inhibition rate (of the pure soil) was moderate $(9.5 \%$ and $12.5 \%$, respectively). This discrepancy can be explained by very low $\mathrm{EC}_{20}$ and $\mathrm{EC}_{10}$ values (Table 8 ), indicating that the avoidance test was very sensitive at the highest level of dilution ( $0.35 \%)$. The repellence of Soil 3 totally disappeared after 6-month biotreatment (Soil 3T), while as mentioned above population growth bioassays still detected some marginal toxicity in this soil. 
A global comparison of ecoscores for the five toxicity and behavioural endpoints

3 (Table 9) showed that lettuce germination and springtail avoidance classified Soil 3 (high

4 content in low molecular weight PAHs) as the most highly threatened soil, while Soils 1

5 and 2 (mixed pollution) exhibited a lower level of toxicity. The toxicity of Soil 3T was not

6 detected by these bioassays after 6 -month biotreatment. However, the toxicity of Soils 1 ,

72 and 3, as measured by ecoscores, was higher with to the springtail avoidance test

$8 \quad(80 \%, 67 \%$ and $100 \%$, respectively) than with the lettuce germination test $(47 \%, 47 \%$ and

$993 \%$, respectively), indicating a better sensitivity of behavioural endpoints. Lettuce growth

10 appeared less sensitive to pollution of Soils 1 and 2 than germination. Earthworm mortality

11 and springtail reproduction tests depicted the same high level of toxicity for Soil 3.

12 However, the toxicity of Soil 2 was revealed by the former and that of Soil 1 by the latter

13 bioassay, which also revealed a marginal toxicity in Soil 3T. By pooling ecoscores for the

14 four soils, the five bioassays can be classified in an increasing order of sensitivity

15 (decreasing ecoscores) according to springtail avoidance $>$ springtail reproduction >

16 lettuce germination > earthworm mortality > lettuce growth (Table 9).

By pooling ecoscores for the five bioassays, the four soils can be classified in an 19 increasing order of toxicity (increasing ecoscores) according to Soil $3 \mathrm{~T}<<$ Soil $2<$ Soil 1 $20<$ Soil 3 (Table 9). Among the different PAHs of the US-EPA list, 3-ring PAHs were those 21 to which most tested bioassays were sensitive. Ecoscores pooled over the five bioassays showed a positive and significant relationship with the concentration of 3-ring PAHs, which explained $90 \%$ of their total variation (Fig. 2). No significant relationship was observed with trace elements.

\section{Discussion}


1 4.1. Different soils may display different responses in toxicity and behavioural laboratory

2 tests

Lors et al. (2006) showed that avoidance by F. candida of a coke factory soil

(diluted to $1 \%$ in a control soil) disappeared after 2 -month incubation at $20^{\circ} \mathrm{C}$ and that this was accompanied by a pronounced diminution of 3- and 4-ring PAHs. All tests performed on Soils 3 and 3T (before and after 6-month windrow biotreatment) showed that the untreated soil was highly acute and chronic toxic (all bioassays responded in the same way, with ecoscores near or equal to 100) and lost all or part of its toxicity after bioremediation (Table 9). However, it should be noticed that the growth of $F$. candida population was still negatively affected, although to a weak extent, after 6-month biotreatment (Table 7). We suspect that the dissipation of PAHs in Soil 3 was incomplete, and that either recalcitrant (high-molecular weight) PAHs were still present (Smith et al., 1999), most probably associated with added organic matter in soil aggregates (Amellal et al., 2001; Nam and Kim, 2002; Nam et al., 2008), or low-molecular weight PAHs were still active at low doses against some sensitive soil fauna (Johnson et al., 2002). The particular toxicity of 3-ring PAHs has been demonstrated at the biomolecular level by Incardona et al. (2005) and was confirmed by our toxicity endpoints. some toxicity, although less than Soil 3, which was detected or not by tested bioassays, according to soil (Table 9). Lettuce and avoidance bioassays detected the toxicity of both soils, while that of Soil 1 was detected by F. candida and not by E. fetida toxicity tests. The contrary was observed for Soil 2 , which exhibited acute toxicity to E. fetida but no chronic toxicity to $F$. candida. These results point to differential sensitivity of test organisms according to nature of pollution. Differences between woodlice and earthworms were clearly assessed in a comparative study by Loureiro et al. (2005), who showed that 
1 according to the nature of contamination they did not respond in the same manner. This

2 urged ecotoxicologists to turn to battery tests using a variety of organisms pertaining to

3 different trophic levels (Pandard et al., 2006; Domene et al., 2008) or to multispecies soil

4 systems (Fernández et al., 2005).

4.2. The choice of a strategy for the laboratory assessment of environmental hazards

7

We showed that over the whole array of studied soils, toxicity and behavioural tests could be compared by their ecoscores, a bulk assessment of total and partial inhibition of biological endpoints, in place or in addition to particular parameters (NOEC, LOEC, $\mathrm{EC}_{50}$ or percent inhibition at the highest concentration) which do not embrace the whole biological response. This method allowed us to classify the avoidance test using $F$. candida as more sensitive than the corresponding reproduction test, and both tests as superior to earthworm and plant bioassays. Similarly, Eom et al. (2007) showed that the $F$. candida reproduction test was more sensitive than earthworm ( $E$. fetida) and plant ( $L$. sativa and Brassica chinensis) tests to PAH soil contamination, but they did not compare them with behavioural tests. Martínez Aldaya et al. (2006) showed that avoidance and reproduction tests using $F$. candida were equally sensitive to coke factory soils but their dose-response curves seem to indicate that behavioural responses were more progressive than toxicity responses, the latter exhibiting clear threshold effects. This might be compared with our avoidance $\mathrm{EC}_{20}$ and $\mathrm{EC}_{10}$ values, which were very low (Table 8) compared to other tests (Tables 4-7). This, together with the higher sensitivity of behavioural tests as estimated by ecoscores (Table 9), suggests that avoidance tests could be preferred when a finer dose-response relationship is requested. Natal-da-Luz et al. (2008b) showed that earthworms (Eisenia andrei) were more sensitive than Collembola ( $F$. candida) to soil texture and thus the latter test organism should be preferred when a large array of soils of different provenances are to be compared. The rapid and stable 
1 response of springtail behavioural tests is remarkable, and we suggest decreasing the

2 exposure time of $24 \mathrm{~h}$ proposed by Natal-da-Luz et al. (2008a) to only $1-2 \mathrm{~h}$, on the base

3 of present study and knowledge on springtail choice ability (Sadaka-Laulan et al., 1998;

4 Salmon and Ponge, 2001; Boitaud et al., 2006).

5

If behavioural tests using soil invertebrates seem justified from an ecological point of view (Yeardley et al., 1996), main criticism lies on whether soil invertebrates are able to perceive pollutants and to escape them before being affected. In case an odour can be detected through the emission of volatiles, which is the case for low molecular weight PAHs, the avoidance test can be efficient and rapid, as most soil animals live in darkness and use odours as clues when foraging (Hedlund et al., 1995; Salmon and Ponge, 2001). The only exception is when mortality is immediate or animals are totally or partly paralysed due to neurotoxic effects of PAHs (Ritchie et al., 2001; Preuss et al., 2003; Martínez Aldaya et al., 2006). Martínez Aldaya et al. (2006) showed that this is a question of dosage, since repellence occurs at very low doses, far below acute toxicity levels.

To the light of our results and after screening published literature, a double strategy could be suggested. Behavioural tests should be preferred to toxicity tests as early assessment tools of soil pollution by PAHs when the level of pollution is expected to be feeble or when nothing is known at all, further completed by reproduction tests (see results on Soil 3T). At higher levels of soil pollution, or in the presence of a mixed pollution by trace elements, a battery of bioassays, combining acute and chronic toxicity tests, should be used, results being combined or compared according to purposes. The use of ecoscores could be useful for such comparisons, because (1) they take into account an array of different toxicity parameters which could be calculated on raw data, and (2) they can be used in further statistical treatment. 


\subsection{Concluding part}

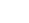

As a conclusion to this section the two questions which were set at the beginning can now be answered. First, it has been shown that the avoidance test, which displayed a sensitive response to most $\mathrm{PAH}$-contaminated soils, gave a better response to all soils and thus could be used as a more sensitive indicator of soil quality. Second, it has been shown that each test or group of tests exhibited a specific response and as a consequence a single test is not enough to assess soil quality. This necessitates adapting the strategy used by the laboratory to the expected level and nature of pollution, in particular when in the presence of a mixed pollution.

\section{Acknowledgements}

The present study was performed with a financial support from the ADEME (Agence de l'Environnement et de la Maitrise de l'Énergie), which is greatly acknowledged. We also thank Y. Barthel and M.J. Jourdain (IRH, France) for their contribution to ecotoxicological analyses.

\section{References}

Amellal, N., Portal, J.M., Berthelin, J., 2001. Effect of soil structure on the bioavailability of polycyclic aromatic hydrocarbons within aggregates of a contaminated soil. Applied Geochemistry 16, 1611-1619.

Amorim, M.J.B., Novais, S., Römbke, J., Soares, A.M.V.M., 2008. Avoidance test with Enchytraeus albidus (Enchytraeidae): effects of different exposure time and soil properties. Environmental Pollution 155, 112-116. 
1 Best, G.R., Nabholz, J.V., Ojasti, J., Crossley, D.A. Jr, 1978. Response of microarthropod populations to naphthalene in three contrasting habitats. Pedobiologia 18, 189201.

Bispo, A., Jourdain, M.J., Jauzein, M., 1999. Toxicity and genotoxicity of industrial soils polluted by polycyclic aromatic hydrocarbons (PAHs). Organic Geochemistry 30, 947-952.

Boitaud, L., Salmon, S., Bourlette, C., Ponge, J.F., 2006. Avoidance of low doses of naphthalene by Collembola. Environmental Pollution 139, 451-454.

Boularbah, A., Schwartz, C., Bitton, G., Morel, J.L., 2006. Heavy metal contamination from mining sites in South Morocco. I. Use of a biotest to assess metal toxicity of tailings and soils. Chemosphere 63, 802-810.

De Silva, P.M.C.S., Van Gestel, C.A.M., 2009. Comparative sensitivity of Eisenia andrei and Perionyx excavates in earthworm avoidance tests using two types in the tropics. Chemosphere 77, 1609-1613.

Domene, X., Alcaniz, J.M., Andrés, P., 2007. Ecotoxicological assessment of organic wasted using the soil collembolan Folsomia candida. Applied Soil Ecology 35, 461472.

Domene, X., Ramírez, W., Mattana, S., Alcañiz, J.M., Andrés, P., 2008. Ecological risk assessment of organic waste amendments using the species sensitivity distribution from a soil organisms test battery. Environmental Pollution 155, 227-236.

Eom, I.C., Rast, C., Veber, A.M., Vasseur, P., 2007. Ecotoxicity of a polycyclic aromatic hydrocarbon (PAH)-contaminated soil. Ecotoxicology and Environmental Safety $67,190-205$.

Fent, K., 2003. Ecotoxicological problems associated with contaminated sites. Toxicology Letters 140/141, 353-365. 
1 Fernández, M.D., Cagigal, E., Vega, M.M., Urzelai, A., Babín, M., Pro, J, Tarazona J.V., 2005. Ecological risk assessment of contaminated soils through direct toxicity assessment. Ecotoxicology and Environmental Safety 62, 174-184.

Ferrari, B., Radetski, C.M., Veber, A.M., Ferard, J.F., 1999. Ecotoxicological assessment of solid wastes: a combined liquid and liquid-phase testing approach using a battery of bioassays and biomarkers. Environmental Toxicology and Chemistry 18, 1195-1202.

Garcia, M., Römbke, J., Torres de Brito, M., Scheffczyk, A., 2008. Effects of three pesticides on the avoidance behavior of earthworms in laboratory tests performed under temperate and tropical conditions. Environmental Pollution 153, 450-456.

Gass, F., Gillet, S., Ponge, J.F., 2006. The use of directional traps fro the assessment of short-term phenanthrene effects upon soil springtail communities. Environmental Pollution 140, 364-370.

Greenslade, P., Vaughan, G.T., 2003. A comparison of Collembola species for toxicity testing of Australian soils. Pedobiologia 47, 171-179.

Hedlund, K., Bengtsson, G., Rundgren, S., 1995. Fungal odour discrimination in two sympatric species of fungivorous collembolans. Functional Ecology 9, 869-875.

Heupel, K., 2002. Avoidance response of different Collembolan species to Betanal. European Journal of Soil Biology 38, 273-276.

Incardona, J.P., Carls, M.G., Teraoka, H., Sloan, C.A., Collier, T.K., Scholz, N.L., 2005. Aryl hydrocarbon receptor-independent toxicity of weathered crude oil during fish development. Environmental Health Perspectives 113, 1755-1762.

ISO, 1993a. ISO 11268-1. Soil quality: effects of pollutants on earthworms (Eisenia fetida). Part 1. Determination of acute toxicity using artificial soil substrate. International Organization for Standardization, Geneva. 
1 ISO, 1993b. ISO 11269-1. Soil quality: determination of the pollutants effects on soil flora. Part 1. Method for the measurement of inhibition of root growth. International Organization for Standardization, Geneva.

ISO, 1995a. ISO 10694. Soil quality: determination of organic carbon and total carbon after dry combustion (elementary analysis). International Organization for Standardization, Geneva.

ISO, 1995b. ISO 11261. Soil quality: determination of total organic nitrogen, modified Kjeldahl method. International Organization for Standardization, Geneva.

ISO, 1998a. ISO 11268-2. Soil quality: effects of pollutants on earthworms (Eisenia fetida). Part 2. Determination of effects on reproduction. International Organization

ISO, 1999. ISO 11267. Soil quality: inhibition of reproduction of Collembola (Folsomia candida) by soil pollutants. International Organization for Standardization, Geneva.

ISO, 2001. ISO 14869-1. Soil quality: dissolution for the determination of total element Organization for Standardization, Geneva.

ISO, 2003. ISO 11262. Soil quality: determination of cyanide. International Organization for Standardization, Geneva.

ISO, 2005a. ISO 11269-2. Soil quality: determination of the pollutants effects on soil flora. Part 2. Effects of chemicals on the emergence and growth of higher plants. International Organization for Standardization, Geneva.

ISO, 2005b. ISO 10390. Soil quality: determination of $\mathrm{pH}$. International Organization for Standardization, Geneva. 
1 ISO, 2008a. ISO 17512-1. Soil quality: avoidance test for determining the quality of soils and effects of chemicals on behaviour. Part 1. Test with earthworms (Eisenia fetida and Eisenia andrei). International Organization for Standardization, Geneva.

ISO, 2008b. ISO 22036. Soil quality: determination of trace elements in extracts of soil by inductively coupled plasma atomic emission spectrometry (ICP-AES). International Organization for Standardization, Geneva.

Jänsch, S., Garcia, M., Römbke, J., 2005. Acute and chronic isopod testing using tropical Porcellionides pruinosus and three model pesticides. European Journal of Soil Biology 41, 143-152.

Johnson, D.L., Jones, K.C., Langdon, C.J., Piearce, T.G., Semple, K.T., 2002. Temporal changes in earthworm availability and extractability of polycyclic aromatic hydrocarbons in soil. Soil Biology and Biochemistry 34, 1363-1370.

Juvonen, R., Martikainen, E., Schulz, E., Joutti, A., Ahtiainen, J., Lehtokari, M., 2000. A battery of toxicity tests as indicators of decontamination in composting oily waste.

Jones, K.C., Stratford, J.A., Waterhouse, K.S., Vogt, N.B., 1989. Organic contaminants in Welsh soils: polynuclear aromatic hydrocarbons. Environmental Science and Technology 23, 540-550. Ecotoxicology and Environmental Safety 47, 156-166.

Kobetičová, K., Hofman, J., Holoubek, I., 2009. Avoidance response of Enchytraeus albidus in relation to carbendazim ageing. Environmental Pollution 157, 704-706.

Lawlor, K., Sublette, K., Duncan, K., Levetin, E., Buck, P., Wells, H., Jennings, E., Hettenbach, S., Bailey, S., Fisher, J.B., Todd, T., 1997. Long-term effects of crude oil contamination and bioremediation in a soil ecosystem. Bioremediation Journal $1,41-51$

Litchfield, J.T., Wilcoxon, F., 1949. A simplified method of evaluating dose-effect experiments. Journal of Pharmacology 96, 99-113. 
1 Lors, C., Martínez Aldaya, M., Salmon, S., Ponge, J.F., 2006. Use of an avoidance test for the assessment of microbial degradation of PAHs. Soil Biology and Biochemistry 38, $2199-2204$.

Lors, C., Périé, F., Grand, C., Damidot, D., 2009. Benefits of ecotoxicological bioassays in the evaluation of a field biotreatment of PAHs polluted soil. Global NEST Journal $11,251-259$.

Loureiro, S., Amorim, M.J.B., Campos, B., Rodrigues, S.M.G., Soares, A.M.V.M., 2009. Assessing joint toxicity of chemicals in Enchytraeus albidus (Enchytraeidae) and Porcellionides pruinosus (Isopoda) using avoidance behavior as an endpoint. Environmental Pollution 157, 625-636.

Loureiro, S., Soares A.M.V.M., Nogueira, A.J.A., 2005. Terrestrial avoidance behaviour tests as screening tool to assess soil contamination. Environmental Pollution 138, 121-131.

Martínez Aldaya, M., Lors, C., Salmon, S., Ponge, J.P., 2006. Avoidance bio-assays may help to test the ecological significance of soil pollution. Environmental Pollution $140,173-180$.

Menzie, C.A., Potocki, B.B., Santodonato, J., 1992. Exposure to carcinogenic PAHs in the environment. Environmental Science and Technology 26, 1278-1284.

Nam, J.J., Thomas, G.O., Jaward, F.M., Steinmes, E., Gustafsson, O., Jones, K.C., 2008. PAHs in background soils from Western Europe: influence of atmospheric deposition and soil organic matter. Chemosphere 70, 1596-1602.

Nam, K., Kim, J.Y., 2002. Role of loosely bound humic substances and humin in the bioavailability of phenanthrene aged in soil. Environmental Pollution 118, 427-433.

Natal-da-Luz, T., Amorin, M.J.B., Römbke, J., Sousa, J.P., 2008a. Avoidance tests with earthworms and springtails: defining the minimum exposure time to observe a significant response. Ecotoxicology and Environmental Safety 71, 545-551. 
1 Natal-da-Luz, T., Römbke, J., Sousa, J.P., 2008b. Avoidance tests in site-specific risk assessment: influence of soil properties on the avoidance response of Collembola and earthworms. Environmental Toxicology and Chemistry 27, 1112-1117.

Natal-da-Luz, T., Ribeiro, R., Sousa, J.P., 2004. Avoidance tests with Collembola and earthworms as early screening tools for site specific assessment of polluted soils. Environmental Toxicology and Chemistry 23, 2188-2193.

Owojori, O.J., Reinecke, A.J., 2009. Avoidance behaviour of two eco-physiologically different earthworms (Eisenia fetida and Aporrectodea caliginosa) in natural and artificial saline soils. Chemosphere 75, 279-283.

Pandard, P., Devillers, J., Charissou, A.M., Poulsen, V., Jourdain, M.J., Férard, J.F., Grand, C., Bispo, A., 2006. Selecting a battery of bioassays for toxicological characterization of wastes. Science of the Total Environment 363, 114-125.

Peralta-Videa, J.R., Gardea-Torresdey, J.L., Gomez, E., Tiemann, K.J., Parsons, J.G., Carrillo, G., 2002. Effect of mixed cadmium, copper, nickel and zinc at different pHs upon alfalfa growth and heavy metal uptake. Environmental Pollution 119, 291-301.

Plaza, G., Nalecz-Jawecki, G., Ulfig, K., Brigmon, R.L., 2005. The application of bioassays as indicators of petroleum-contaminated soil remediation. Chemosphere 59, 289296.

Preuss, R., Angerer, J., Drexler, H., 2003. Naphthalene: an environmental and occupational toxicant. International Archives of Occupational and Environmental Health 76, 556-576. 
1 Rila, J.P., Eisentraeger, A., 2003. Application of bioassays for risk characterization and remediation control of soils polluted with nitroaromatics and PAHs. Water, Air, and Soil Pollution 48, 223-242.

Ritchie, G.D., Still, K.R., Alexander, W.K., Nordholm, A.F., Wilson, C.L., Rossi, J. III, Mattie, D.R., 2001. A review of the neurotoxicity risk of selected hydrocarbon fuels. Journal of Toxicology and Environmental Health, Part B, Reviews 4, 223-312.

Römbke, J., 2003. Ecotoxicological laboratory tests with enchytraeids: a review. Pedobiologia 47, 607-616.

Sadaka-Laulan, N., Ponge, J.F., Roquebert, M.F., Bury, E., Boumezzough, A., 1998. Feeding preferences of the Collembolan Onychiurus sinensis for fungi colonizing holm oak litter (Quercus rotundifolia Lam.). European Journal of Soil Biology 34, 179-188.

Salminen, J., Sulkava, P., 1996. Distribution of soil animals in patchily contaminated soil.

Salmon, S., Ponge, J.F., 1998. Responses to light in a soil-dwelling springtail. European Journal of Soil Biology 34, 199-201.

Salmon, S., Ponge, J.F., 2001. Earthworm excreta attract soil springtails: laboratory experiments on Heteromurus nitidus (Collembola: Entomobryidae). Soil Biology and Biochemistry 33, 1959-1969.

Smith, M.J., Lethbridge, G., Burns, R.G., 1999. Fate of phenanthrene, pyrene and benzo[a]pyrene during biodegradation of crude oil added to two soils. FEMS Microbiology Letters 173, 445-452.

Sterckeman, T., Douay, F., Proix, N., Fourrier, H., Perdrix, E., 2002. Assessment of the contamination of cultivated soils by eighteen trace elements around smelters in the North of France. Water, Air, and Soil Pollution 135, 173-194.

Verschueren, K., 2001. Handbook of Environmental Data on Organic Chemicals, fourth ed. Wiley, New York. 
1 Yeardley, R.B.Jr, Lazorchak, J.M., Gast, L.C., 1996. The potential of an earthworm avoidance test for evaluation of hazardous waste sites. Environmental Toxicology and Chemistry 15, 1532-1537.

4 


\section{Figure captions}

2

3 Fig. 1. Concentrations of 2- to 6-ring PAHs in the four studied soils. Values are means of 4 three replicate dosages, with S.D. as error bars

5

6 Fig. 2. Correlation between mean ecoscores (bulked for five different bioassays) and 7 concentrations of 3-ring PAHs in the four studied soils. ${ }^{*}=$ significant at 0.05 risk 8 level

9 
1 Table 1. Main physicochemical characteristics of the four studied soils

2

\begin{tabular}{llllllll}
\hline & Texture & $\begin{array}{l}\text { Moisture } \\
(\%)\end{array}$ & $\mathrm{pH}_{\text {water }}$ & $\begin{array}{l}\text { Total carbon } \\
(\%)\end{array}$ & $\begin{array}{l}\text { Total organic } \\
\text { carbon } \\
(\%)\end{array}$ & $\begin{array}{l}\text { Total organic } \\
\text { nitrogen } \\
\left(\mathrm{mg} \mathrm{kg}^{-1}\right)\end{array}$ & $\begin{array}{l}\text { Total } \\
\text { phosphorus } \\
\left(\mathrm{mg}^{\mathrm{kg}} \mathrm{kg}^{-1}\right)\end{array}$ \\
\hline Soil 1 & silty sand & $9.0 \pm 0.2$ & $8.1 \pm 0.02$ & $9.7 \pm 0.2$ & 9.2 & 1300 & 770 \\
Soil 2 & sand & $18.9 \pm 0.6$ & $7.8 \pm 0.03$ & $44.3 \pm 1.4$ & 44.2 & 5600 & 1900 \\
Soil 3 & sand & $17.4 \pm 0.1$ & $7.9 \pm 0.02$ & $11.2 \pm 0.6$ & $9.0 \pm 0.5$ & 1700 & 620 \\
Soil 3T & sand & $16.3 \pm 0.3$ & $8.3 \pm 0.01$ & $8.6 \pm 0.2$ & $5.7 \pm 0.1$ & 2088 & 670 \\
\hline
\end{tabular}

3

4 Means of three replicated measures followed by standard deviations. Concentrations are expressed on a dry soil basis

6 
1 Table 2. Concentration ( $\mathrm{mg} \cdot \mathrm{kg}^{-1}$ ) of cyanides and heavy metals in the four studied soils,

2 compared with the geochemical background

3

\begin{tabular}{|c|c|c|c|c|c|c|c|c|c|c|}
\hline & \multirow[t]{2}{*}{$\Sigma 16 \mathrm{PAHs}$} & \multirow[t]{2}{*}{ Cyanides } & \multicolumn{8}{|c|}{ Heavy metals } \\
\hline & & & As & Cd & Co & $\mathrm{Cr}$ & $\mathrm{Cu}$ & $\mathrm{Ni}$ & $\mathrm{Pb}$ & $\mathrm{Zn}$ \\
\hline Soil 1 & $701 \pm 84$ & 6.6 & $21.7 \pm 1.6$ & $<4$ & $8.0 \pm 0.1$ & $31.9 \pm 0.7$ & $47.8 \pm 3.8$ & $21.1 \pm 0.3$ & $35.1 \pm 3.8$ & $75.1 \pm 11.9$ \\
\hline Soil 2 & $3687 \pm 85$ & 67 & $33.4 \pm 2.6$ & $5.2 \pm 0.01$ & $48.9 \pm 1.4$ & $52.2 \pm 4.0$ & $126.4 \pm 0.3$ & $46.9 \pm 1.9$ & $345.7 \pm 7.0$ & $514 \pm 10.6$ \\
\hline Soil 3 & $2895 \pm 54$ & 0.8 & $6.5 \pm 0.5$ & $<4$ & $9.6 \pm 0.2$ & $32.9 \pm 0.3$ & $19.3 \pm 0.4$ & $19.8 \pm 0.2$ & $23.9 \pm 0.8$ & $92.7 \pm 0.8$ \\
\hline Soil 3T & $345 \pm 41$ & 0.5 & $6.5 \pm 0.9$ & $<4$ & $8.9 \pm 0.1$ & $31.3 \pm 0.9$ & $21 \pm 0.6$ & $26.8 \pm 3.3$ & $25.9 \pm 3.7$ & $104 \pm 5.8$ \\
\hline Control 1 & $1.2 \pm 0.1$ & 0.2 & $20.3 \pm 2.8$ & $<4$ & $7.6 \pm 0.4$ & $39.4 \pm 3.3$ & $8.9 \pm 0.3$ & $19.1 \pm 0.8$ & $7.1 \pm 0.003$ & $39.0 \pm 1.9$ \\
\hline Control 2 & $8.6 \pm 0.7$ & 0.2 & $18.6 \pm 0.9$ & $<4$ & $9.9 \pm 0.4$ & $25.5 \pm 0.5$ & $26.0 \pm 1.2$ & $17.3 \pm 0.7$ & $38.6 \pm 1.2$ & $87.6 \pm 2.0$ \\
\hline Control 3 & $1.0 \pm 0.7$ & 0.1 & $6.7 \pm 0.8$ & $<4$ & $9.1 \pm 0.4$ & $39.2 \pm 1.3$ & $14.8 \pm 0.2$ & $27.0 \pm 2.3$ & $19.9 \pm 0.9$ & $67.9 \pm 1.1$ \\
\hline $\begin{array}{l}\text { Geochemical } \\
\text { background }\end{array}$ & & & $8.9 \pm 1.2$ & $0.4 \pm 0.03$ & $9.3 \pm 0.9$ & $48.8 \pm 2.7$ & $16.7 \pm 1.8$ & $24.7 \pm 5.7$ & $38.4 \pm 5.6$ & $73.7 \pm 6.2$ \\
\hline
\end{tabular}

4

5 Means of three replicated measures followed by standard deviations. Background

6 concentrations have been measured over a wide range of unpolluted agricultural and

7 forest soils (Sterckeman et al., 2002). Concentrations are expressed on a dry soil basis 
1 Table 3. Concentrations of 16 PAHs of the US-EPA list in the four studied soils

\begin{tabular}{lllll}
\hline & Soil 1 & Soil 2 & Soil 3 & Soil 3T \\
\hline Naphthalene & $19.2 \pm 0.7$ & $150.9 \pm 10.6$ & $594.2 \pm 13.8$ & $11.1 \pm 4.9$ \\
Acenaphtylene & $1.9 \pm 0.04$ & $23.5 \pm 1.1$ & $3.1 \pm 0.1$ & $0.2 \pm 0.4$ \\
Acenaphtene & $1.9 \pm 0.04$ & $2 \pm 0.1$ & $217.4 \pm 1.2$ & $7.4 \pm 0.6$ \\
Fluorene & $19.3 \pm 0.3$ & $83.1 \pm 3.7$ & $226.8 \pm 2.8$ & $4.5 \pm 4.2$ \\
Phenanthrene & $119.4 \pm 17.7$ & $308.2 \pm 17.7$ & $629.3 \pm 4.2$ & $3.8 \pm 0.8$ \\
Anthracene & $183.2 \pm 8.3$ & $206.7 \pm 7$ & $202.5 \pm 31.7$ & $19.1 \pm 5.9$ \\
Fluoranthene & $130.8 \pm 22.5$ & $625.2 \pm 30.7$ & $414.3 \pm 1.2$ & $55.1 \pm 11.9$ \\
Pyrene & $54.5 \pm 9.9$ & $299.4 \pm 10.9$ & $233.4 \pm 0.4$ & $50.6 \pm 9.9$ \\
Benzo[a]anthracene & $48.4 \pm 9.2$ & $391.9 \pm 13.1$ & $85.7 \pm 0.9$ & $21.2 \pm 2.9$ \\
Chrysene & $47.7 \pm 8.2$ & $410.4 \pm 8.1$ & $75.4 \pm 0.9$ & $19.0 \pm 2.7$ \\
Benzo[b]anthracene & $2.6 \pm 1$ & $210.8 \pm 5.8$ & $56.2 \pm 0.3$ & $42.9 \pm 5.4$ \\
Benzo[k]fluoranthene & $2.8 \pm 0.8$ & $161.9 \pm 2.6$ & $25.8 \pm 0.3$ & $15.7 \pm 1.7$ \\
Benzo[a]pyrene & $38.2 \pm 2.6$ & $364.1 \pm 2.9$ & $60.4 \pm 6.7$ & $37.1 \pm 4.8$ \\
Dibenzo[ah]anthracene & $4.9 \pm 0.5$ & $59.3 \pm 0.3$ & $6.9 \pm 0.2$ & $1.4 \pm 0.1$ \\
Benzo[ghi]perylene & $15.1 \pm 1.5$ & $196.1 \pm 6.5$ & $32.5 \pm 1$ & $21.4 \pm 4.2$ \\
Indeno[123-cd]pyrene & $11.2 \pm 1$ & $193.7 \pm 1.6$ & $30.8 \pm 0.3$ & $34.8 \pm 5.3$ \\
\hline
\end{tabular}

3

4 Means of three replicated measures followed by standard deviations. Concentrations are 5 expressed on a dry soil basis 
1 Table 4. Toxicity of the four studied soils according to the Lactuca sativa germination

2 bioassay

3

\begin{tabular}{|c|c|c|c|c|c|c|c|}
\hline & $\begin{array}{c}E_{50} \\
\left(\mathrm{~g} .100 \mathrm{~g}^{-1}\right)\end{array}$ & $\begin{array}{c}\text { TU } \\
100 / \mathrm{EC}_{50}\end{array}$ & $\begin{array}{c}E_{20} \\
\left(\mathrm{~g} .100 \mathrm{~g}^{-1}\right)\end{array}$ & $\begin{array}{c}E_{10} \\
\left(\mathrm{~g} .100 \mathrm{~g}^{-1}\right)\end{array}$ & $\begin{array}{c}\text { NOEC } \\
\left(\mathrm{g} .100 \mathrm{~g}^{-1}\right)\end{array}$ & $\begin{array}{c}\text { Inhibition } \\
(\%)\end{array}$ & $\begin{array}{c}\text { Ecoscore } \\
(\%)\end{array}$ \\
\hline Soil 1 & $>100$ & $<1$ & $\begin{array}{c}64.9 \\
(48.9-86.2)\end{array}$ & $\begin{array}{c}25.3 \\
(13.5-47.5)\end{array}$ & $<35$ & 20.4 & 47 \\
\hline Soil 2 & $>100$ & $<1$ & $\begin{array}{c}80.8 \\
(62.9->100)\end{array}$ & $\begin{array}{c}41.7 \\
(29.9-58.1)\end{array}$ & $<35$ & 21.4 & 47 \\
\hline Soil 3 & $\begin{array}{c}21.3 \\
(15.5-29.3)\end{array}$ & 4.5 & $\begin{array}{c}3.5 \\
(1.9-6.5)\end{array}$ & $\begin{array}{c}1.4 \\
(0.6-3.4)\end{array}$ & $<5$ & 70.9 & 93 \\
\hline Soil 3T & NT & NT & NT & NT & NT & 0 & 0 \\
\hline
\end{tabular}

4

$5 \mathrm{EC}_{50}, \mathrm{EC}_{20}, \mathrm{EC}_{10}=$ concentration causing $50 \%, 20 \%, 10 \%$ inhibition of germination rate,

6 respectively (confidence interval at 0.05 risk level between brackets); $T U=100 / E_{50}$;

$7 \quad \mathrm{NOEC}=$ no observed effect concentration; NT = not toxic, observed response statistically

8 indistinguishable from unpolluted soil sampled on the studied site; inhibition = relative

9 decrease in response (\%) compared to control soil at the highest dose tested 
1 Table 5. Toxicity of the four studied soils according to the Lactuca sativa growth inhibition

2 bioassay

3

\begin{tabular}{|c|c|c|c|c|c|c|c|}
\hline & $\begin{array}{c}\mathbf{E C}_{50} \\
\left(\mathrm{~g} .100 \mathrm{~g}^{-1}\right)\end{array}$ & $\begin{array}{c}\text { TU } \\
100 / \mathrm{EC}_{50}\end{array}$ & $\begin{array}{c}\mathbf{E C}_{20} \\
\left(\mathrm{~g} .100 \mathrm{~g}^{-1}\right)\end{array}$ & $\begin{array}{c}E_{10} \\
\left(\mathrm{~g} .100 \mathrm{~g}^{-1}\right)\end{array}$ & $\begin{array}{c}\text { NOEC } \\
\left(\mathrm{g} .100 \mathrm{~g}^{-1}\right)\end{array}$ & $\begin{array}{c}\text { Inhibition } \\
(\%)\end{array}$ & $\begin{array}{c}\text { Ecoscore } \\
(\%)\end{array}$ \\
\hline Soil 1 & $>100$ & $<1$ & $>100$ & $\begin{array}{c}87.4 \\
(72.5->100)\end{array}$ & 100 & 0.7 & 13 \\
\hline Soil 2 & $>100$ & $<1$ & $>100$ & $\begin{array}{c}95.1 \\
(83.5->100)\end{array}$ & 60 & 10 & 20 \\
\hline Soil 3 & $\begin{array}{c}16.6 \\
(13.1-21.0)\end{array}$ & 5.8 & $\begin{array}{c}2.9 \\
(1.7-4.8)\end{array}$ & $\begin{array}{c}1.2 \\
(0.6-2.4)\end{array}$ & $<5$ & 79.3 & 93 \\
\hline Soil 3T & NT & NT & NT & NT & NT & 0 & 0 \\
\hline
\end{tabular}

4

$5 \mathrm{EC}_{50}, \mathrm{EC}_{20}, \mathrm{EC}_{10}=$ concentration causing $50 \%, 20 \%, 10 \%$ inhibition of growth rate,

6 respectively (confidence interval at 0.05 risk level between brackets); $T U=100 / E_{50}$;

$7 \quad \mathrm{NOEC}=$ no observed effect concentration; NT = not toxic, observed response statistically

8 indistinguishable from unpolluted soil sampled on the studied site; inhibition = relative

9 decrease in response (\%) compared to control soil at the highest dose tested 
1 Table 6. Toxicity of the four studied soils according to the Eisenia fetida mortality bioassay

2

\begin{tabular}{|c|c|c|c|c|c|c|c|}
\hline & $\begin{array}{c}\mathbf{L C}_{50} \\
\left(\mathrm{~g} .100 \mathrm{~g}^{-1}\right)\end{array}$ & $\begin{array}{c}\text { TU } \\
100 / \mathrm{LC}_{50}\end{array}$ & $\begin{array}{c}\mathbf{L C}_{20} \\
\left(\mathrm{~g} .100 \mathrm{~g}^{-1}\right)\end{array}$ & $\begin{array}{c}\text { LC }_{10} \\
\left(\mathrm{~g} .100 \mathrm{~g}^{-1}\right)\end{array}$ & $\begin{array}{c}\text { NOEC } \\
\left(\mathrm{g} .100 \mathrm{~g}^{-1}\right)\end{array}$ & $\begin{array}{c}\text { Inhibition } \\
(\%)\end{array}$ & $\begin{array}{c}\text { Ecoscore } \\
(\%)\end{array}$ \\
\hline Soil 1 & NT & NT & NT & NT & NT & 0 & 0 \\
\hline Soil 2 & $\begin{array}{c}>100 \\
(97.8->100)\end{array}$ & $<1$ & $\begin{array}{c}88.0 \\
(83.0-93.2)\end{array}$ & $\begin{array}{c}79.1 \\
(72.2-86.7)\end{array}$ & 60 & 37.5 & 33 \\
\hline Soil 3 & $\begin{array}{c}0.60 \\
(0.56-0.64)\end{array}$ & 167 & $\begin{array}{c}0.51 \\
(0.46-0.55)\end{array}$ & $\begin{array}{c}0.46 \\
(0.41-0.51)\end{array}$ & 0.4 & 100 & 100 \\
\hline Soil 3T & NT & NT & NT & NT & NT & 0 & 0 \\
\hline
\end{tabular}

3

$4 \mathrm{LC}_{50}, \mathrm{LC}_{20}, \mathrm{LC}_{10}=$ concentration causing $50 \%, 20 \%, 10 \%$ inhibition of survival rate,

5 respectively (confidence interval at 0.05 risk level between brackets); $T U=100 / \mathrm{LC}_{50}$;

$6 \quad$ NOEC $=$ no observed effect concentration; NT = not toxic, observed response statistically

7 indistinguishable from unpolluted soil sampled on the studied site; inhibition = relative

8 decrease in response (\%) compared to control soil at the highest dose tested

9 
1 Table 7. Toxicity of the four studied soils according to the Folsomia candida population

2 growth bioassay

3

\begin{tabular}{|c|c|c|c|c|c|c|c|}
\hline & $\begin{array}{c}\mathbf{E C}_{50} \\
\left(\mathrm{~g} .100 \mathrm{~g}^{-1}\right)\end{array}$ & $\begin{array}{c}\text { TU } \\
100 / \mathrm{EC}_{50}\end{array}$ & $\begin{array}{c}\mathbf{E C}_{20} \\
\left(\mathrm{~g} .100 \mathrm{~g}^{-1}\right)\end{array}$ & $\begin{array}{c}\mathbf{E C}_{10} \\
\left(\mathrm{~g} .100 \mathrm{~g}^{-1}\right)\end{array}$ & $\begin{array}{c}\text { NOEC } \\
\left(\mathrm{g} .100 \mathrm{~g}^{-1}\right)\end{array}$ & $\begin{array}{c}\text { Inhibition } \\
(\%)\end{array}$ & $\begin{array}{c}\text { Ecoscore } \\
(\%)\end{array}$ \\
\hline Soil 1 & $\begin{array}{c}93.5 \\
(75.3->100)\end{array}$ & 1.1 & $\begin{array}{c}37.0 \\
(30.0-45.7)\end{array}$ & $\begin{array}{c}22.8 \\
(17.2-30.3)\end{array}$ & 10 & 63.6 & 60 \\
\hline Soil 2 & NT & NT & NT & NT & NT & 0 & 0 \\
\hline Soil 3 & $\begin{array}{l}2.2 \\
N / A\end{array}$ & 45.5 & $\begin{array}{l}2.1 \\
N / A\end{array}$ & $\begin{array}{r}1.9 \\
N / A\end{array}$ & 1 & 100 & 100 \\
\hline Soil 3T & $>100$ & $<1$ & $>100$ & $\begin{array}{c}5.2 \\
(1.8-15.1)\end{array}$ & $<0.35$ & 27 & 53 \\
\hline
\end{tabular}

4

$5 \mathrm{EC}_{50}, \mathrm{EC}_{20}, \mathrm{EC}_{10}=$ concentration causing $50 \%, 20 \%, 10 \%$ inhibition of population growth

6 rate, respectively (confidence interval at 0.05 risk level between brackets); $T U=100 / E_{50}$;

$7 \quad$ NOEC $=$ no observed effect concentration; NT = not toxic, observed response statistically

8 indistinguishable from unpolluted soil sampled on the studied site; inhibition = relative

9 decrease in response (\%) compared to control soil at the highest dose tested; N/A =

10 cannot be calculated 
1 Table 8. Avoidance of the four studied soils by Folsomia candida

2

\begin{tabular}{|c|c|c|c|c|c|c|c|}
\hline & $\begin{array}{c}\mathrm{EC}_{50} \\
\left(\mathrm{~g} .100 \mathrm{~g}^{-1}\right)\end{array}$ & $\begin{array}{c}\text { TU } \\
100 / \mathrm{EC}_{50}\end{array}$ & $\begin{array}{c}\mathrm{EC}_{20} \\
\left(\mathrm{~g} .100 \mathrm{~g}^{-1}\right)\end{array}$ & $\begin{array}{c}\text { EC }_{10} \\
\left(\mathrm{~g} .100 \mathrm{~g}^{-1}\right)\end{array}$ & $\begin{array}{c}\text { NOEC } \\
\left(\mathrm{g} .100 \mathrm{~g}^{-1}\right)\end{array}$ & $\begin{array}{c}\text { Inhibition } \\
(\%)\end{array}$ & $\begin{array}{c}\text { Ecoscore } \\
(\%)\end{array}$ \\
\hline Soil 1 & $\begin{array}{c}27.1 \\
(19.5-37.6)\end{array}$ & 3.7 & $\begin{array}{c}2.9 \\
(2.0-4.3)\end{array}$ & $\begin{array}{c}0.9 \\
(0.5-1.6)\end{array}$ & $<0.35$ & 9.5 & 80 \\
\hline Soil 2 & $>100$ & $<1$ & $\begin{array}{c}1.7 \\
(0.6-5.1)\end{array}$ & $\begin{array}{c}0.04 \\
(0.004-0.403)\end{array}$ & $<0.35$ & 12.5 & 67 \\
\hline Soil 3 & $\begin{array}{c}0.8 \\
(0.6-1)\end{array}$ & 129 & $\begin{array}{c}0.3 \\
(0.2-0.4)\end{array}$ & $\begin{array}{c}0.042 \\
(0.008-0.205)\end{array}$ & $<0.35$ & 100 & 100 \\
\hline Soil 3T & NA & NA & NA & NA & NA & 0 & 0 \\
\hline
\end{tabular}

3

$4 \mathrm{EC}_{50}, \mathrm{EC}_{20}, \mathrm{EC}_{10}=$ concentration causing $50 \%, 20 \%, 10 \%$ avoidance rate, respectively 5 (confidence interval at 0.05 risk level between brackets); $T U=100 / \mathrm{EC}_{50} ; \mathrm{NOEC}=$ no 6 observed effect concentration; NA = not avoided, observed response statistically 7 indistinguishable from unpolluted soil sampled on the studied site; inhibition = relative 8 decrease in response (\%) compared to control soil at the highest dose tested 
1 Table 9. Eco-scores of the four studied soils obtained with five different bioassays. Total

2 ecoscores are average values of the five tested bioassays (rows) or of the four soils

3 (columns)

4

\begin{tabular}{lcccccc}
\hline & $\begin{array}{c}\text { Lettuce } \\
\text { germination }\end{array}$ & $\begin{array}{c}\text { Lettuce } \\
\text { growth } \\
\text { inhibition }\end{array}$ & $\begin{array}{c}\text { Earthworm } \\
\text { mortality }\end{array}$ & $\begin{array}{c}\text { Springtail } \\
\text { reproduction }\end{array}$ & $\begin{array}{c}\text { Springtail } \\
\text { avoidance }\end{array}$ & Total \\
\hline Soil 1 & 47 & 13 & 0 & 60 & 80 & 40 \\
Soil 2 & 47 & 20 & 33 & 0 & 67 & 33 \\
Soil 3 & 93 & 93 & 100 & 100 & 100 & 97 \\
Soil 3T & 0 & 0 & 0 & 53 & 0 & 11 \\
\hline Total & 47 & 32 & 33 & 53 & 62 & \\
\hline
\end{tabular}

5 


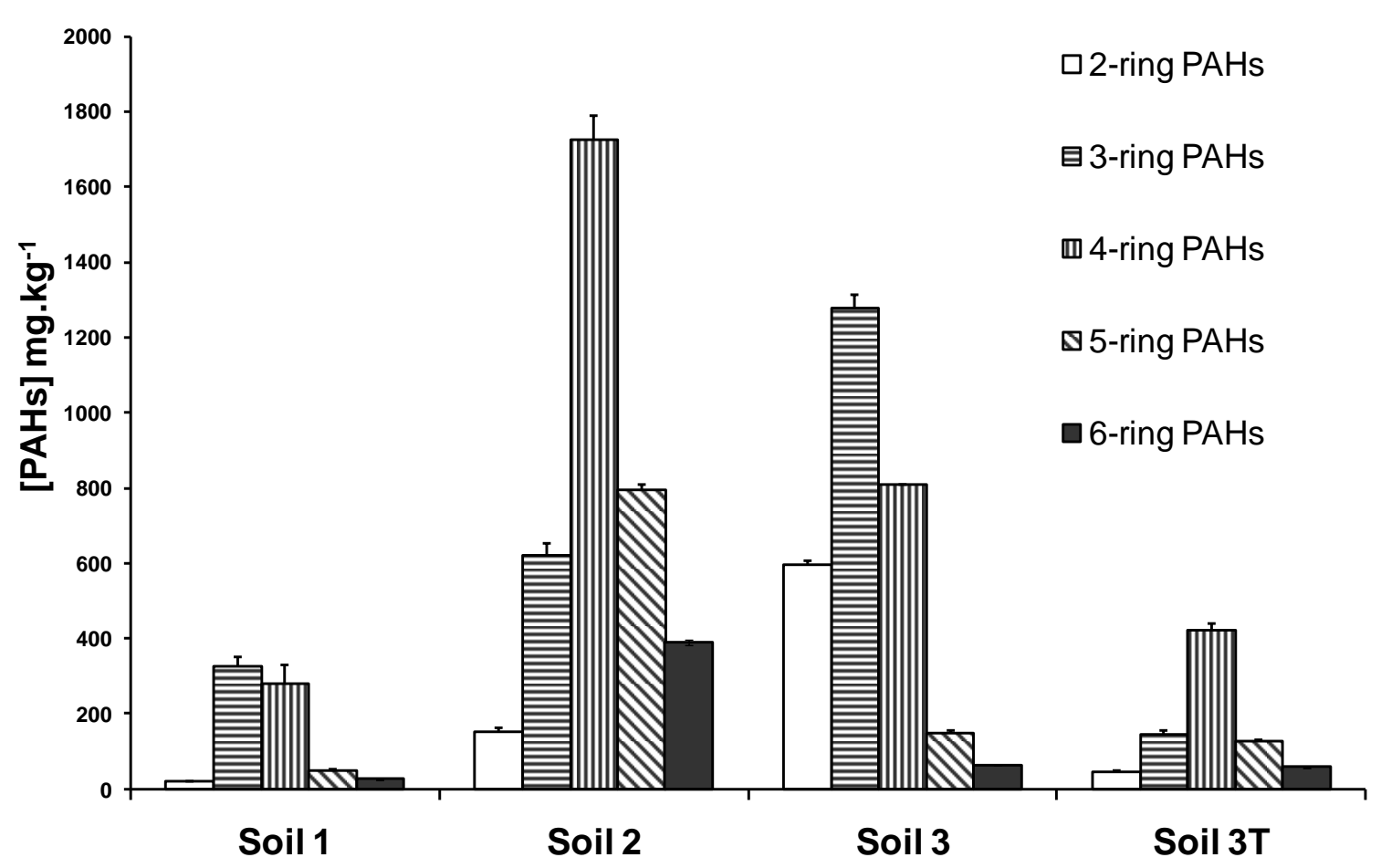

2 Fig. 1

3 


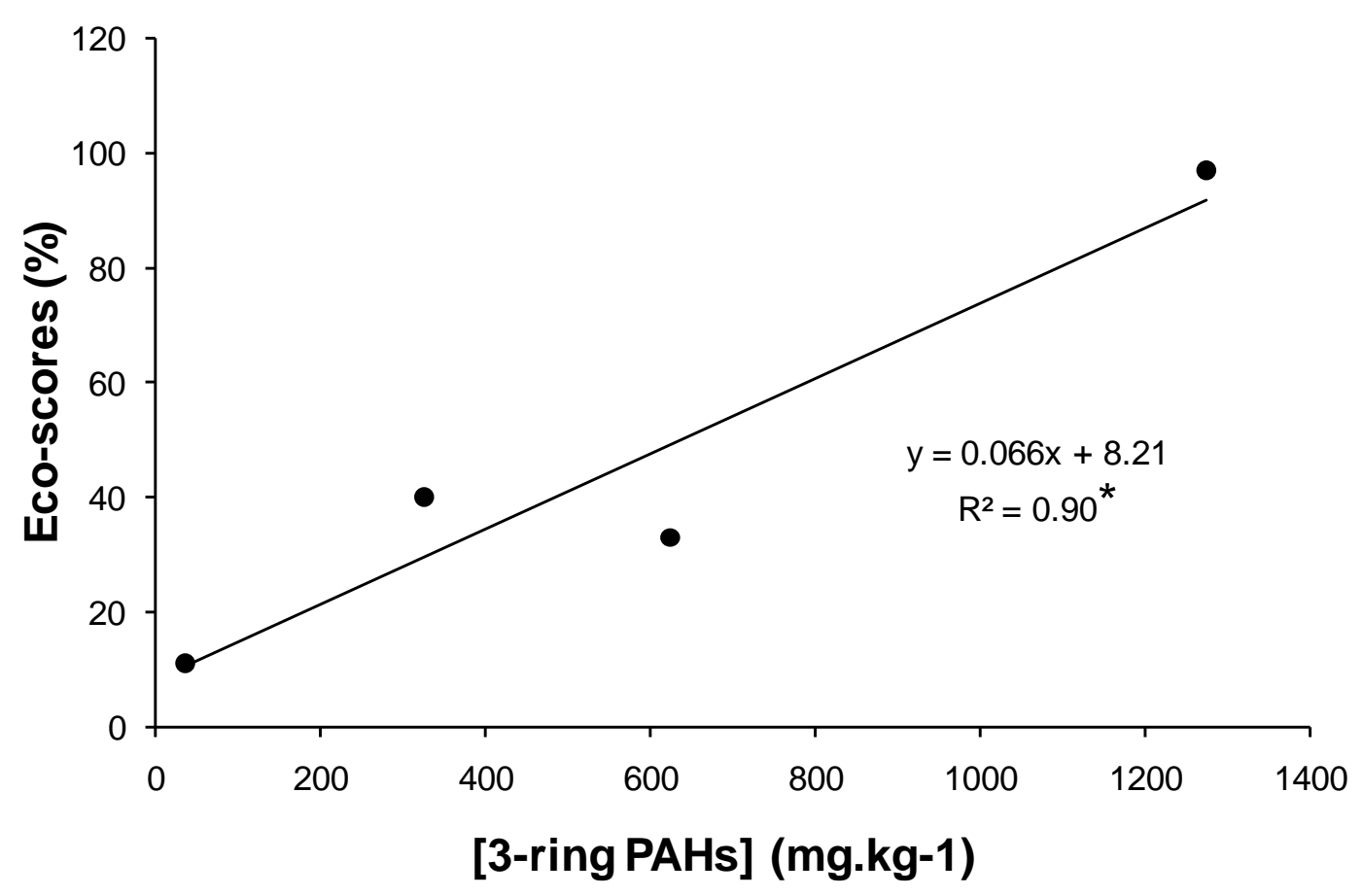

1

Fig. 2 